\title{
An approach on phytoalexins: function, characterization and biosynthesis in plants of the family Poaceae
}

Uma abordagem sobre fitoalexinas: função, caracterização e biossíntese em plantas da família Poaceae

\author{
Rejanne Lima Arruda ${ }^{I^{*}}$ Andressa Tuane Santana Paz ${ }^{\mathrm{I}}$ Maria Teresa Freitas Bara \\ Márcio Vinicius de Carvalho Barros CôrtesII Marta Cristina Corsi de Filippi ${ }^{\text {II }}$ \\ Edemilson Cardoso da Conceição ${ }^{I}$
}

ABSTRACT

Phytoalexins are compounds that have been studied a few years ago, which present mainly antimicrobial activity. The plants of the family Poaceae are the most geographically widespread and stand out for their economic importance, once they are cereals used as staple food. This family stands out for having a variety of phytoalexins, which can be synthesized via the shikimic acid (the phenylpropanoids), or mevalonic acid, being considered terpenoid phytoalexins. The characterization of these compounds with antimicrobial activity is carried out using chromatographic techniques, and the high-performance liquid chromatography (HPLC) coupled with mass spectrometry are the most efficient methods in this process. This research aimed to present an approach of the function, characterization and biosynthesis of phytoalexins in plants of the family Poaceae.

Key words: metabolites, protection of plants, signaling, Oryza sativa.

\section{RESUMO}

As fitoalexinas são compostos que vêm sendo estudados há alguns anos, apresentando principalmente atividade antimicrobiana. As plantas da família Poaceae são as geograficamente mais difundidas e se destacam por sua importância econômica, uma vez que são os cereais que compõe a base da alimentação, em todos os continentes. Essa família se destaca por apresentar uma variedade de fitoalexinas, sendo que as mais importantes são sintetizadas a partir da via do ácido chiquímico. A caracterização desses compostos com atividade antimicrobiana é realizada por meio de técnicas cromatográficas, sendo que a cromatografia líquida de alta eficiência (HPLC) acoplada com espectrometria de massas é a técnica mais eficiente nesse processo. O trabalho apresenta como objetivo uma abordagem da função, caracterização, biossintese e aplicações das fitoalexinas em plantas da família Poaceae.
Palavras-chave: metabólitos, proteção de plantas, sinalização, Oryza sativa.

\section{INTRODUCTION}

Phytoalexins are natural products secreted and accumulated temporarily by plants in response to pathogen attack. They have inhibitory activity against bacteria, fungi, nematodes, insects and toxic effects for the animals and for the plant itself (BRAGA, 1991). They are mostly lipophilic compounds that have the ability to cross the plasma membrane and act inside the cell. According to SMITH (1996) their toxicity in the plant occurs as a function of their acidic character, the high number of hydroxyl and substituents.

CAVALCANTI et al. (2005) states that the mode of action of phytoalexins on fungi includes cytoplasmic granulation, disorganization of the cellular contents, rupture of the plasma membrane and inhibition of fungal enzymes, reflecting on the inhibition of seed germination and elongation of the germ tube and reduction or inhibition of mycelial growth.

According to GRAYER \& KOKUBUN (2001) phytoalexins are secondary metabolites of low molecular weight, so that it can not be applied to antifungal proteins and peptides produced by plants, once they have higher molecular weight. STOESSL

ILaboratório de PD\&I de Bioprodutos, Faculdade de Farmácia, Universidade Federal de Goiás (UFG), 74605-170, Goiânia, GO, Brasil. E-mail: rejanne.lima.arruda@hotmail.com. *Corresponding author.

"Laboratório de Fitopatologia, Embrapa Arroz e Feijão, Santo Antônio de Goiás, GO, Brasil. 
et al. (1980) defined the phytoalexins as products of the metabolism of higher plants absent in healthy tissues or present only in insignificant amounts, which accumulate in significant quantities in response to attack by fungi or bacteria.

Pisatin was the first chemically characterized phytoalexin from pea plants. After this discovery, other phytoalexins were isolated from various crops such as beans, rice, barley, banana, among others (BRAGA, 1991).

The phytoalexins have great diversity, and more than 300 types have been characterized amongst different classes of chemical compounds such as coumarins, diterpenes, flavonoid, alkaloids, phenolic compounds, luteolinidin, apigenidin and apigeninidin (HARBONE, 1999; CALVALCANTE, 2005), these being used as chemical markers in several studies. The rate of phytoalexin accumulation is considered a key factor for the establishment of the pathogen infection.

Synthesis of phytoalexin in response to pathogen attack can be modified with the influence of various factors as temperature, humidity and water availability. Several parts of the plant can produce phytoalexins such as leaves, flowers, stems, seeds and root tubers (MIKKELSEN et al., 2003).

Some compounds can act as a phytoalexin in a plant organ and be constitutive in another part of the same plant, such as momilactone A, which occurs constitutively in rice husks, and rice stems (LEE et al., 1999), but is a phytoalexin in rice leaves (CARTWRIGHT et al., 1981). TOYOMASU et al. (2008) also reported that momilactone $A$ is constitutively produced and exuded from root. Thus, phytoalexins are defined by the dynamics of their biosynthesis and function, not by the class of chemical structure to which they belong, or biosynthetic pathway through which they were formed.

According to AHUJA et al. (2012) phytoalexins have been identified in several plant families such as Brassicaceae, Fabaceae, Solanaceae, Vitaceae and Poaceae in response to the infection by pathogens or treatment with elicitors. Studies of phytoalexins in Poaceae are stimulated by the extensive cultivation of cereals of this family in the world, and their importance in feeding. Therefore, studies have been carried out aiming to explore the phytoalexins produced in various parts of plants of this family to defend against pathogenic microorganisms, and also to investigate the use of substances isolated from these plants to induce the synthesis of phytoalexins (CHUKWUNUNSO et al., 2013). Table 1 illustrates the main phytoalexin of different plant families. This paper presents a review on the function, characterization and biosynthesis of phytoalexins identified in plants of the family Poaceae.

\section{Phytoalexins in Poaceae}

The family Poaceae (Gramineae) presents 13 subfamilies comprising 793 genera and 10,000 species. Plants of the family Poaceae are geographically the most widespread on Earth. In Brazil, there is a record of 197 genera and 1, 368 species (SÁNCHEZ$\mathrm{KEN}$ et al., 2007). The family is ranked in third place in number of genera, and is the fifth in number of species, occupying the first place in the economy, mainly in the production of sugar, cereals, pasture and bamboo. This family has great ecological and economic importance by the dominance in various plant ecosystems, by its use in animal nutrition and the participation of cereals in the diet of half of the global population (SÁNCHEZ-KEN et al., 2007; WELKER \& LONGHI-WAGNER, 2007).

GALHANO \& TALBOT (2011) state that among the cereal cultivated plants belonging to the family Poaceae, rice is the most important member providing the majority of the world's caloric intake. Poaceae plants have also been studied for the production of a variety of compounds which are classified as phytoalexins (AHUJA, 2012). Some members of this family, including rice, maize and sorghum, are known by the production of substantial amounts of groups of phytoalexins. Other cereals such as wheat and barley, although having certain phytoalexin biosynthesis genes, still has no phytoalexin identified. (CHUKWUNONSO et al., 2013. This can be explained by the absence of the specific elicitor phytoalexin for the gene expression of these plants, since it is of secondary metabolism products that is required phenotypic changes elicited by the action of biotic or abiotic agents.

Members of the family Poaceae produce mainly diterpenoid phytoalexins. Corn yield diterpenoid phytoalexins named kauralexins (Figure 1-A and B) and acid sesquiterpenoids known as zealexins (C and D) (Figure 1). The elicitors of phytoalexins in corn include pathogens such as Aspergillus flavus, Aspergillus sojae, Cochliobolus heterostrophus, Colletotrichum sublineolum, Fusarium graminearum, Ostrinianubilalis, Rhizopus microspores and Ustilago maydis (HUFFAKER et al., 2011).

Sorghum produces two distinct 3-deoxyanthocyanidin phytoalexins known as apigeninidin (2-(4-hydroxyphenyl) benzopyrilium chloride) and luteolinidin (2-(3,4-dihydroxyphenyl)chromenylium 5,7-diol) (Figure 2). Biosynthesis of 3-deoxyanthocyanidin phytoalexins is independent 
Table 1 - The main phytoalexin of different plant families.

\begin{tabular}{|c|c|c|}
\hline Plant families & Type of Phytoalexins/Exemplos & References \\
\hline Amaryllidaceae & Flavans & COXON, 1980 \\
\hline Brassicaceae (Cruciferae) & Indole phytoalexins/camalexin Sulfur-containing phytoalexins/brassinin & BROWNE, 1991 \\
\hline Chenopodiaceae & Flavanones/betagarin Isoflavones/betavulgarin & PEDRAS, 2000 \\
\hline Compositae & Polyacetylenes/safynol & GEIGERT, 1973 \\
\hline Convolvulaceae & Furanosesquiterpenes/Ipomeamarone & ALLEN, 1971 \\
\hline Euphorbiaceae & Diterpenes/casbene & URITANI, 1960 \\
\hline Poaceae & $\begin{array}{l}\text { Diterpenoids:Momilactones; Oryzalexins; Zealexins; Phytocassanes; } \\
\text { Kauralexins Deoxyanthocyanidins/luteolinidin and apigeninidin } \\
\text { Flavanones/sakuranetin Phenylamides }\end{array}$ & $\begin{array}{l}\text { SITTON, } 1975 \\
\text { POLONI, } 2014 \\
\text { LIN PARK, } 2013 \\
\text { JEANDET, } 2013\end{array}$ \\
\hline Leguminosae & $\begin{array}{l}\text { Isoflavones Isoflavanones Isoflavans Coumestans Pterocarpans/pisatin, } \\
\text { phaseollin, glyceollin and maiackiain Furanoacetylenes/wyerone } \\
\text { Stilbenes/resveratrol Pterocarpens }\end{array}$ & JEANDET, 2013 \\
\hline Linaceae & Phenylpropanoids/coniferyl alcohol & KEEN, 1975 \\
\hline Malvaceae & Terpenoids naphtaldehydes/gossypol & SUNILKUMAR, 2006 \\
\hline Moraceae & Furanopterocarpans/moracins A-H & TAKASUGI, 1979 \\
\hline Orchidaceae & Dihydrophenanthrenes/loroglossol & WARD, 1975 \\
\hline Rutaceae & Methylated phenolic compounds/xanthoxylin & $\begin{array}{l}\text { HARTMANN, } 1974 \\
\text { HARDING, } 1981\end{array}$ \\
\hline Umbelliferae & Polyacetylenes/falcarinol Phenolics: xanthotoxin 6-methoxymellein & $\begin{array}{l}\text { JOHNSON, } 1973 \\
\text { CONDON, } 1963\end{array}$ \\
\hline Vitaceae & Stilbenes/resveratrol & LANGCAKE, 1976 \\
\hline Rosaceae & Biphenyls/auarperin Dibenzofurans/cotonefurans & KOKOBUN, 1995 \\
\hline Solanaceae & $\begin{array}{l}\text { Phenylpropanoid related compounds and references therein Steroid } \\
\text { glycoalkaloids Norsequi and sesquiterpenoids Coumarins Polyacetylenic } \\
\text { derivatives }\end{array}$ & JEANDET, 2013 \\
\hline
\end{tabular}

(JEANDET, 2014).

of light, it occurs in the dark, in contrast to the light dependent anthocyanin biosynthesis (flavonoid compounds, which are plant pigments) (WHARTON \& NICHOLSON, 2000).

According to HUANG \& BACKHOUSE (2004), the induction of 3-deoxyanthocyanidin is not the only level of defense used by sorghum against pathogens. They showed that sorghum inoculated with Fusarium proliferatum, and Fusarium thapsinum, increased the levels of apigeninidin and luteolinidin, as well as the concentrations of the resistance-related proteins peroxidases, $\beta-1,3$ glucanases and chitinases.

Phytoalexins in rice

Rice (Oryza sativa, Gramineae) is among the most important staple foods in the world. Some serious diseases such as blast, which is caused by the fungus Pyricularia oryzae (Magnaporthe oryzae), can cause considerable losses in productivity, leading to a major economic loss for the population
(GRAYER \& KOKUBUN, 2001). Thus, studies have been carried out to develop more resistant cultivars. One potential strategy to confer resistance in rice plants is the manipulation of their innate defense mechanisms, which can be induced by a variety of biotic and abiotic factors (LI et al, 2014). These factors have the ability to induce plant defense through the production of PRPs (resistance-related proteins), phytoalexins, hypersensitivity response and systemic acquired resistance.

The phytoalexins that more accumulates in response to the attack of pathogens in rice plants are compounds of the class of diterpenes (Solenoids) such as momilactone A, B and phytocassane A-E. From the class of flavonoids, only one was identified, the sakuranetin (5,4'-dihydroxy-7-methoxyflavanone) (Figure 3) (AJUHA et al, 2012).

According to OKADA (2007) the diterpenoid phytoalexins are classified into four distinct types of polycyclic diterpenes based on the 
<smiles>COC(=O)C1=CC=C(C2=CCC(C(=O)OC)CC2)CC1</smiles>

Figure 1 - Structure of phytoalexins produced by corn plants.

structure of their hydrocarbon diterpene precursors: phytocassanes A-E, A-F oryzalexins, momilactones A and $\mathrm{B}$ and oryzalexin S (Figure 3 ). Two diterpenoid phytoalexins have been reported; phytocassane $\mathrm{F}$ and ent-10-oxodepressin (INOUE, 2013; HORIE, 2015).

KOGA et al. (1995) cites that phytocassanes $\mathrm{A}, \mathrm{B}, \mathrm{C}$ and $\mathrm{D}$ are produced by induction mediated by infection with the pathogens Magnaporthe oryzae and Rhizoctonia solani. However, the phytocassanes E are induced by the pathogen Phytophthora infestans and have antifungal action against Magnaporthe oryzae.

KOGA et al. (1997) reports that the antimicrobial action of phytocassanes $\mathrm{B}, \mathrm{C}$ and $\mathrm{E}$ has $\mathrm{EC}_{50}$ values of 4-7ug ml-1, four times greater than the phytocassanes $\mathrm{A}$ and $\mathrm{D}$. This can be explained by the presence of the group B hydroxyl at the $\mathrm{C}-1$ position of these phytocassanes which can form hydrogen bond with the carbonyl group at $\mathrm{C}-11$.

The Momilactones A and B exert antifungal action against Magnaporthe oryzae, Botrytis cinerae, Fusarium solani, Fusarium oxysporum, Colletrotichum gloesporides. These phytoalexins possess antibacterial activity against Escherichia coli, Pseudomonas ovalis, Bacillus pumilus and Bacillus cereus (FUKUTA et al., 2007).
The phytoalexin sakuranetin (flavonoid) is an antifungal compound present in the leaves of black currant, and in rice leaves, they are induced at the moment of the pathogen attack (KODAMA et al., 1992).

Characterization and methods of detection of phytoalexins

NUGROHO et al. (2002), evaluating the accumulation of induced phytoalexins in tobacco plants showed that an efficient analysis in the identification of phytoalexins of the sesquiterpene group (Capsidiol, phytuberin and phytuberol) is the use of a gas chromatograph equipped with an autosampler and flame ionisation detector to identify the Capsidiol. The identification of these phytoalexins was carried out after the extraction process using ethanol, $\mathrm{MeOH}$ and chloroform and liquid nitrogen for the tissues maceration.

To analyze the sakuranetin (flavonoid) in rice leaves, KODAMA et al. (1992), injected the leaf extract using a HPLC C18 column equilibrated with $\mathrm{C}_{6} \mathrm{H}_{6}$ (benzene)-Et OAc (ethyl acetate) $-\mathrm{HCO}_{2} \mathrm{H}$ (formic acid) at a ratio of (10:1:1). The sakuranetin was detected by UV at a wavelength of $285 \mathrm{~nm}$.

PEDRAS et al. (2006) reported the identification of 23 cruciferous phytoalexins by 


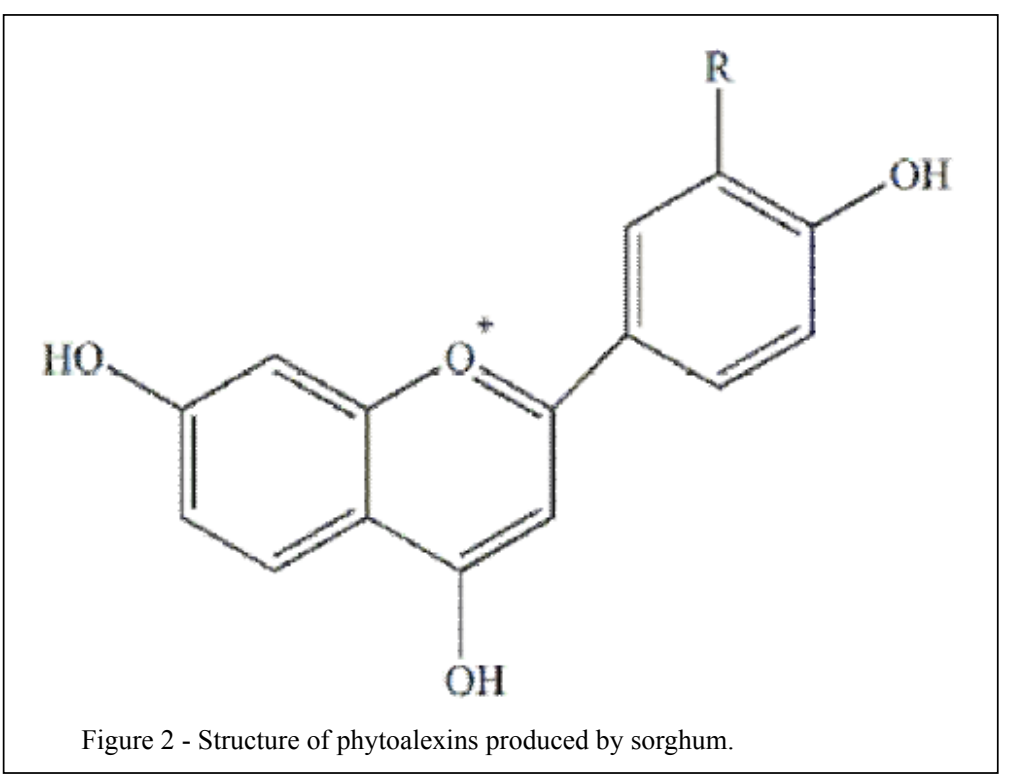

HPLC analysis with diode array detection and mass spectrometry with electro spray ionization using positive and negative ion modes. According to the authors, the positive ion modes were more sensitive than the negative mode.

SHIMIZU et al. (2008) have created a protocol for rapid and accurate quantification of two phytoalexins in rice (phytocassanes and momilactones), using high-performance liquid chromatography and mass spectrometry with electrospray ionization as analytical method. The levels of these phytoalexins are commonly analyzed by gas chromatography. The method was very efficient in quantifying the phytocassanes and momilactones, which were induced by the cholic acid and by the oligosaccharide elicitor chitin. According to the authors, the HPLC method is more advantageous than gas chromatography, once the HPLC coupled with mass spectrometry (MS) in tandem provides a quantitation method which does not require complicated purification steps such as derivatization and has no need for high temperatures. Momilactones A and B yielded the precursor ions and protonated molecular ions with $\mathrm{m} / \mathrm{z} 315$ and $\mathrm{m} / \mathrm{z} 331$, respectively, and the ions of the characteristic products at $\mathrm{m} / \mathrm{z} 271\left(\left[\mathrm{M}+\mathrm{H}-\mathrm{CO}_{2}\right]+\right)$ and $\mathrm{m} / \mathrm{z} 269\left(\left[\mathrm{~m}+\mathrm{H}-\mathrm{H}_{2} \mathrm{O}-\right.\right.$ $\left.\mathrm{CO}_{2}\right]+$ ), respectively, in the positive ion mode.

Biosynthesis of phytoalexins

Most of the identified phytoalexins derive from the phenylpropanoidbiosynthetic pathway, which are a class of organic compounds synthesized from the amino acid phenylalanine. The phenylpropanoids are involved in various functions and play a vital role in the interaction between the plant and the environment. Many secondary metabolites are involved in the resistance to plant diseases, namely: isoflavones, coumarins, stilbenes, dihydrophenanthrene, lignin and other phenols. Enzymes that catalyze the biosynthesis of phytoalexins are: Phenylalanine ammonia lyase (PAL), cinnamate 4 hydrolase, and coenzyme 4-cumaraseligase (MATEOS \& LEAL, 2013). The knowledge of the biosynthetic pathways of phytoalexins and the involved enzymes lead to the knowledge of the expression of plant response to an infection by pathogens. Terpenoid phytoalexins exist in a variety of species, such as tobacco (Nicotiana tabacum), cotton (Gossypium hirsutum), sweet potato (Ipomoea batatas) and elm (Ulmus americana). Despite the great diversity of monocots, ranging from palm trees, orchids, ginger, lilies, onions and herbs, so far, the largest group of terpenoid phytoalexins of Poaceae occur in the genera Oryza and Zea (HARBORNE, 1999).

In plants, the isopentenyl diphosphate and dimethylallyl pyrophosphate (DMAPP) isoprenoid precursors can be derived from the mevalonate or metileritritol phosphate. The methylerythritol phosphate (MEP) pathway leads to the biosynthesis of geranylgeranyl diphosphate and the diterpenoid biosynthesis pathway (OKADA, 2007). The pathways proposed by TOYOMASU (2008) for the biosynthesis of diterpenoid phytoalexins in rice are illustrated in figure 4 . The diterpene cyclases catalyze the conversion of ent-copalyl-diphosphate (ent-CDP) or syn-copalyl- 


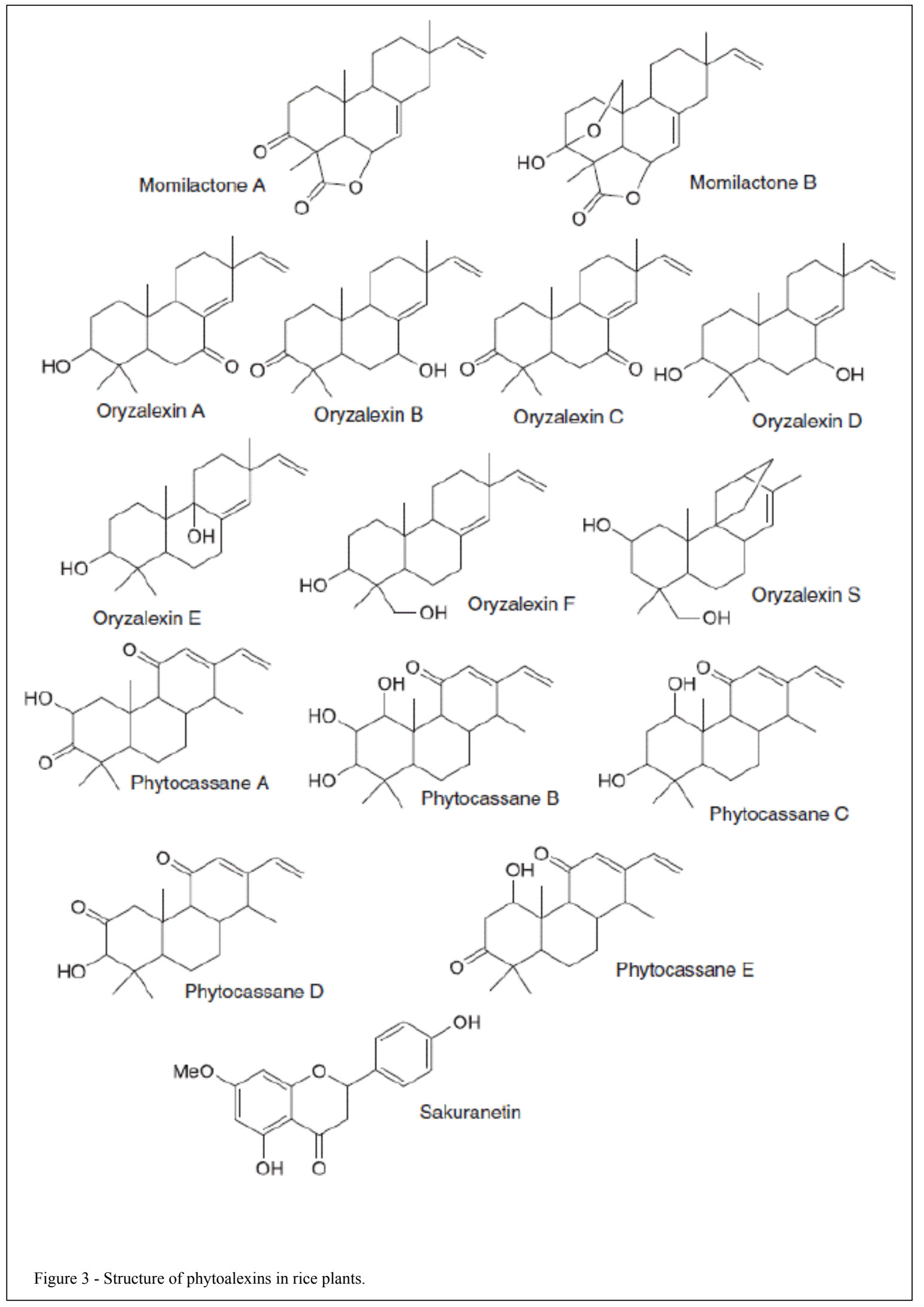

Ciência Rural, v.46, n.7, jul, 2016. 


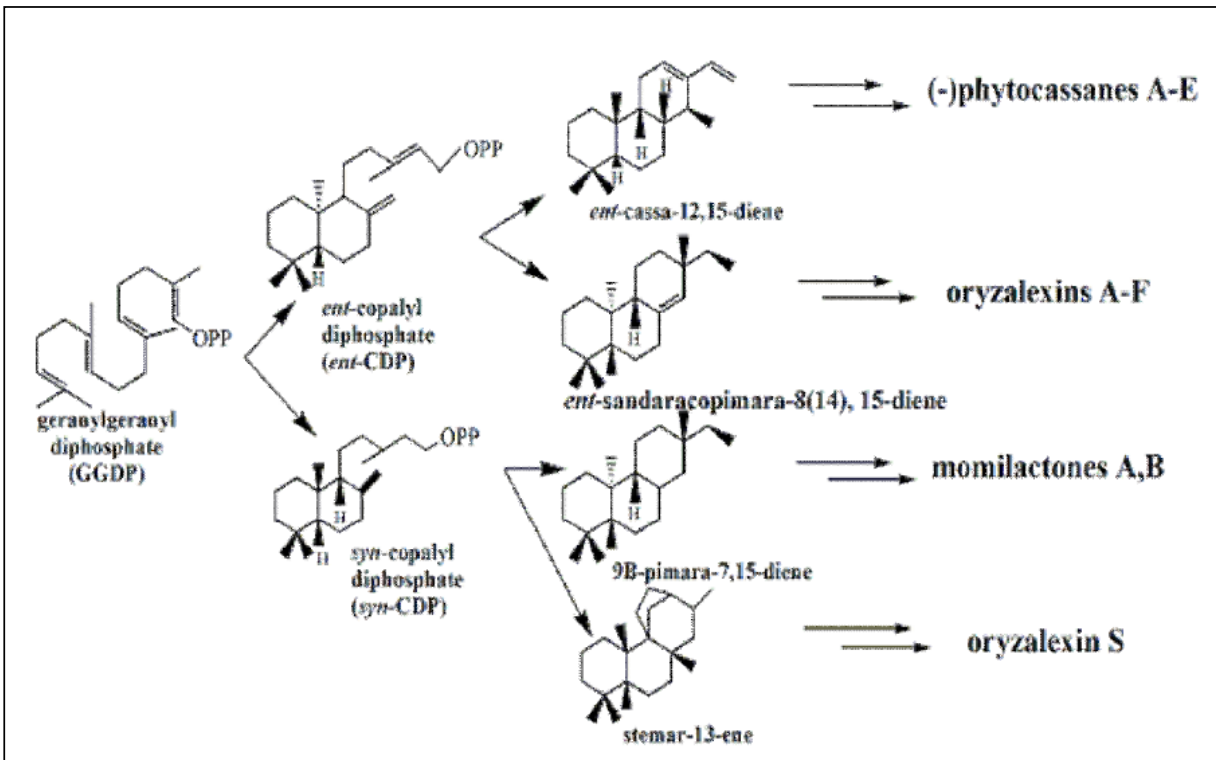

Figure 4 - Biosynthesis of diterpene phytoalexins in rice.

diphosphate (syn-CDP) in four key hydrocarbons in the phytoalexin biosynthesis in rice, which are: entcassa-12,15-diene; ent-sandaracopimara-8(14),15diene; 9ß-pimara-7,15-diene and stemar-13-ene.

The geranylgeranyl diphosphate production in rice probable occur in the plastids by methylerythritol phosphate pathway, whereas sesquiterpenes and triterpenes are usually synthesized in the cytoplasm through the mevalonate pathway (VRANOVA et al., 2013). Diterpenoid phytoalexins are expected to arise through the diphosphate geranylgeranyl methylerythritol.

Phytoalexins the process of plant resistance to pathogens Plant pathogens have evolved numerous strategies for obtaining nutritious materials from plants, which in turn, evolved preformed chemical and physical barriers as well as the immune system to combat the pathogen attack. These two types of defense are considered as constituting, if they are already present before the infection, or induced, if it results from host-pathogen interaction (BRAGA \& DIETRICH, 1987; ZHANG et al., 2013).

Plants usually produce more than 100,000 natural products of low molecular weight - the secondary metabolites, which differ from the primary because they are not essential to plant life (DOMINGO
\& LÓPEZ-BREA, 2003). Some metabolites act as antimicrobials, working in defense against plant pathogens. These substances can be divided into two major groups: phytoanticipins, which are constitutive in plants and phytoalexins that increase considerably in response to the attack of insects and other animals (BRAGA \& DIETRICH, 1987).

Although fungi are the agents most commonly used in the study of induction of phytoalexins, bacteria, viruses, nematodes and stimuli from abiotic origin can also induce the accumulation of these defense substances in plants. The process of induced defense involves the activation of latent resistance mechanisms in plants in response to prior treatment with biotic and abiotic agents (LI etal., 2014). Among the biotic elicitors, which are characterized by viable or inactivated microorganisms, plant extracts have been widely used to promote the induction of resistance, once these products have the advantages of not being phytotoxic and are readily biodegradable (DEVAIAH, 2009). Once they are no pathogenic organisms, their mechanism of action is the induced systemic resistance, not causing symptoms such as necrosis and activating the defense response of plants such as the production of PRPs and phytoalexins.

The innate response of plant defense is activated through two mechanisms, which are, PAMP- 
triggered immunity (PTI), also known as basal or nonhost defense and "effector-triggered immunity" (ETI) or host-specific resistance. The PTI defense mechanism occurs soon after contact with the pathogen, and is considered the first line of innate immunity in plants (ZHANG \& ZHOU, 2010). This is based on the highly specific interaction between the pathogen effectors and the products of the $R$ gene, according to the Gene for Gene Theory (BOLLER \& FELIX, 2009).

Depending on the signaling pathway, which leads to the expression of defenses, the induction of resistance can be divided into induced (ISR), that is activated by non-pathogenic microorganisms and is mediated by jasmonate and ethylene, and acquired (SAR), which is activated by pathogenic microorganisms, and is a salicylate-dependent induction (PIETERSE et al., 2001; ZHANG et al., 2015).

The knowledge of these pathways is important for choosing the most appropriate elicitor agent to trigger the desired defense system and thus obtain the highest expression of these antimicrobial compounds.

\section{CONCLUSION}

Identification of phytoalexins in a particular species supports the findings of future elicitors of synthesis of active compounds in plant defense against biotic stresses. The search for molecules in other similar plant species, which could be extracted in large scale and used to stimulate other plants producing these compounds, is an effective mechanism that can provide greater protection to these plants.

Vegetable extracts contain a complexity of secondary metabolites, which act synergistically to combat plant pathogens and can be used as a matrix for the isolation and synthesis of specific active molecules, facilitating large-scale use.

Because these are compounds that are extracted from plants, they can present phytoalexins, which contribute to an increased expression of these compounds in plants used in the study.

The synthesis of phytoalexins mechanism has not yet been developed and thus the means of obtaining this is restricted to the process of isolation and identification, which requires a greater expenditure of time and lower yield.

The cost and time for the execution of the insolation process makes few researchers able to develop the identification of phytoalexins, due to the lack of specific standards for such identification. Besides the need to obtain these standards, the research to find the best elicitors for each species studied becomes necessary, because once it comes secondary metabolism products; factors are needed for this induction.

The use of more advanced techniques such as proteomics or metabolomics, which are intended to identify and quantify the set of metabolites produced or modified by a body, are tools available that can serve as a more complete process of analysis of phytoalexins. The molecular biology study became a strategy that has been extensively analyzed because knowledge of expressed genes facilitates the identification of species with similar defense response characteristics and allows the extraction and identification of these phytoalexins through a bank of genomic data.

Prospects for further studies to evaluate the discovery of new phytoalexins identification mechanisms, as well as research that prove their activities and the application process for this mechanism to reduce production losses of important crops for human consumption, like the Poaceae family, can collaborate to improve the quality of products supplied to the population.

\section{ACKNOWLEDGEMENTS}

Fundação de Amparo à Pesquisa do Estado de Goiás (FAPEG), Coordenação de Aperfeiçoamento de Pessoal de Nível Superior (CAPES) - 474353/2013-3 Universal Edital 14/2013.

\section{REFERENCES}

AHUJA, I. et al. Phytoalexins in defense against pathogens. Trends Plant Science, v.17, n.2, p.73-90, 2012. Available from: <http:// www.sciencedirect.com/science/article/pii/S1360138511002457>. Accessed: Oct. 10, 2015. doi:10.1016/j.tplants.2011.11.002.

ALLEN, E.H.; THOMAS, C.A. Trans-trans-3,11-tridecadiene5,7,9-triyne-1,2-diol, an antifungal polyacetylene from diseased safflower (Carthamus tinctorius). Phytochemistry, v.10, p.15791582, 1971. Available from: <http://www.sciencedirect.com/ science/article/pii/0031942271850276>. Accessed: Set. 01, 2015. doi:10.1016/0031-9422(71)85027-6.

BOLLER, T.; FELIX, G. A renaissance of elicitors: perception of microbe-associated molecular patterns and danger signals by pattern-recognition receptors. Annual Review Plant Biology, v 60, p.379-406, 2009. Available from: $<$ http://www.annualreviews.org/ doi/pdf/10.1146/annurev.arplant.57.032905.105346>. Accessed: Set. 01, 2015. doi: 10.1146/annurev.arplant.57.032905.105346.

BRAGA, M.R. et al. Phytoalexins induction in Rubiacea. Journal of Chemical Ecology, v.17, p.1079-1090, 1991. Available from: $<$ http://link.springer.com/article/10.1007\%2FBF01402935>. Accessed: Set. 02, 2015. doi: 10.1007/BF01402935.

BRAGA, M.R.; DIETRICH, S.M.C. Defesas químicas de plantas: Fitoalexinas. Acta Botanica Brasilica, v.1, n.1, p.3-16, 1987. Available from: <http://www.scielo.br/scielo.php?pid=S0102- 
33061987000100002\&script $=$ sci_abstract $>$. Accessed: Set. 02, 2015. doi: 10.1590/S0102-33061987000100002.

BROWNE, L.M. et al. The camalexins: New phytoalexins produced in the leaves of Camelia sativa (Cruciferae). Tetrahedron, v.47, p.3909-3914, 1991. Available from: < http://www.sciencedirect. com/science/article/pii/S0040402001864310>. Accessed: Set. 02, 2015. doi: 10.1016/S0040-4020(01)86431-0.

CARTWRIGHT, P. Isolation and characterization of two phytoalexins from rice as momilactones A and B. Phytochemistry, v.20, p.535-537, 1981. Available from: <http://www.sciencedirect. com/science/article/pii/S0031942200841898>. Accessed: Out. 01, 2015. doi: 10.1016/S0031-9422(00)84189-8.

CAVALCANTI, L.S. et al. Aspectos bioquímicos e moleculares da resistência induzida. In: _. et al. (Eds.). Indução de resistência em plantas a patógenos e insetos. Piracicaba: FEALQ, v.81, p.124, 2005. Available from: <http://www.scielo.br/ scielo.php?script $=$ sci_arttext\&pid $=\mathrm{S} 0100-54052009000300001>$. Accessed: Ago.10, 2015. doi: 10.1590/S0100-54052009000300001

CHUKWUNONSO, E.C.C.E. et al. Phytoalexins from the Poaceae: Biosyntesis, function and prospects in food preservation. Food Reviews International. v.52, n.1, p.167-177, 2013. Available from: $<$ http://www.sciencedirect.com/science/article/pii/ S0963996913001750>. Accessed: Out. 01, 2015. doi: 10.1016/j. foodres.2013.03.012.

CONDON, P. et al. Production of 3-methyl-6-methoxy8-hydroxy-3, 4-dihydroisocoumarin by carrot root tissue. Phytopathology, v.53, p.1244-1250, 1963. Available from: $<$ http:// aem.asm.org/content/29/5/706.full.pdf>. Accessed: Ago. 10, 2015. doi: $10.3109 / 15569543.2011 .550862$

COXON, D.T. et al. Identification of three hydroxyflavan phytoalexins from daffodil bulbs. Phytochemistry, v.19, p.889891, 1980. Available from: <http://www.sciencedirect.com/ science/article/pii/0031942280851326>. Accessed: Out. 01, 2015 doi: 10.1016/0031-9422(80)85132-6.

DEVAIAH, S.P. et al. Induction of systemic resistance in pearl millet (Pennisetum glaucum) against downy mildew (Sclerospora graminicola) by Datura metel extract. Crop Protection, v.28, n.9, p.783-791, 2009. Available from: <http://www.sciencedirect. com/science/article/pii/S0261219409000982>. Accessed: Out. 01, 2015. doi: 10.1016/j.cropro.2009.04.009.

DOMINGO, D.; LOPEZ-BREA, M. Plantas com acción antimicrobiana. Revista Española de Quimioterapia, v.16, n.4, p.385-393, 2003. Available from: <https://www.researchgate.net/ publication/28066457 Plantas con accion antimicrobiana>. Accessed: Out. 01, 2015. ISSN 0214-3429.

FUKUTA, M. et al. Comparative efficacies in vitro of antibacterial, fungicidal, antioxidant, and herbicidal activities of momilactones A and B. Journal of Plant Interaction, v.2, p.245251, 2007. Available from: <http://www.tandfonline.com/doi/ full/10.1080/17429140701713811\#.VsGzyvkrLIU>. Accessed: Out.01, 2015. doi: 10.1080/17429140701713811.

GALHANO, R; TALBOT, N.J. The biology of blast: Understanding how Magnaporthe oryzae invades rice plants. Fungal Biology Review, v.25, n.1, p.61-67, 2011. Available from: <http://www. sciencedirect.com/science/article/pii/S1749461311000108>. Accessed: Out. 20, 2015. doi: 10.1016/j.fbr.2011.01.006.
GEIGERT, J. et al. Two phytoalexins from sugarbeet (Beta vulgaris) leaves. Tetrahedron, v.29, p.2703-2706, 1973 Available from: <http://www.sciencedirect.com/science/article/ pii/S0040402001933897>. Accessed: Out. 20, 2015. doi: 10.1016/ S0040-4020(01)93389-7.

GRAYER R.J.; KOKUBUN, T. Plant-fungal interactions: the search for phytoalexins and other antifungal compounds from higher plants. Phytochesmistry, v.56, p.253-263, 2001. Available from: <http://www.sciencedirect.com/science/article/ pii/S0031942200004507>. Accessed: Ago. 20, 2015. doi: 10.1016/ S0031-9422(00)00450-7.

HARDING, V.K.; HEALE, J.B. The accumulation of inhibitory compounds in the induced resistance response of carrot root slices to Botrytis cinerea. Physiology of Plant Pathology, v.18, p.7-15, 1981. Available from: $<$ http://www.sciencedirect.com/science/article/pii/ S0048405981800483?np=y>. Accessed: Ago.20,2015. doi: 10.1016/S0048-4059(81)80048-3.

HARTMANN, G.; NIENHAUS, F. The isolation of xanthoxylin from the bark of Phytophthora- and Hendersonula-infected Citrus lemon and its fungitoxic effect. Phytopathology, v.81, p.97-113, 1974. Available from: <http://www.cabdirect.org/ abstracts/19750327248.html>. Accessed: Jul. 10, 2015. Record Number: 19750327248 .

HARBONE, J.B. The comparative biochemistry of phytoalexins induction in plants. Biochemistry Systematics and Ecology, v.27, p.335-367, 1999. Available from: <http://www.sciencedirect. com/science/article/pii/S0305197898000957>. Accessed: Jul. 10, 2015. doi: 10.1016/S0305-1978(98)00095-7.

HORIE, K. et al. Identification of UV-induced Diterpenes including a new Diterpene Phytoalexin, Phytocassane F, from rice leaves by complementary GC/MS and LC/MS approaches. Journal of Agricultural and Food Chemistry, v.63, n.16, p.4050-4059, 2015. Available from: <http://pubs.acs.org/ doi/abs/10.1021/acs.jafc.5b00785>. Accessed: Jul. 10, 2015. doi: $10.1021 /$ acs.jafc.5b00785.

HUANG, L.D; BACKHOUSE, D. Effects of Fusarium species on defence mechanisms in sorghum seedlings. N.Z. Plant Protection, v.57, p.121-124, 2004. Available from: <https://www. nzpps.org/journal/57/nzpp 571210.pdf>. Accessed: Jul. 23, 2015. doi: 10.1111/j.1439-0434.2005.01013.x.

HUFFAKER, A. et al. Novel acidic sesquiterpenoids constitute a dominant class of pathogen-induced phytoalexins in maize. Plant physiology, v.156, p.2082-2097, 2011. Available from: <http:// www.ncbi.nlm.nih.gov/pubmed/21690302>. Accessed: Jul. 23, 2015. doi: 10.1104/pp.111.179457.

INOUE, Y. et al. Identification of a novel casbane-type diterpene phytoalexin, ent-10-oxodepressin, from rice leaves. Bioscience Biotechnology and Biochemisty, v.77, n.4, p.760-765, 2013. Available from: <http://www.tandfonline. com/doi/abs/10.1271/bbb.120891>. Accessed: Jul. 10, 2015. doi:10.1271/bbb. 120891 .

JEANDET, P. et al. Modulation of phytoalexin biosynthesis in engineered plants for disease resistance. International Journal of Molecular Sciences, v.14, p.14136-14170, 2013. Available from: $<$ http://www.ncbi.nlm.nih.gov/pubmed/23880860>. Accessed: Jun. 22, 2015. doi: 10.3390/ijms140714136. 
JEANDET, P. et al. Deciphering the role of Phytoalexins in plantmicroorganism interactions and human health. Molecules, v.19, p.18033-18056, 2014. Available from: <http://www.ncbi.nlm.nih. gov/pubmed/25379642>. Accessed: Jun. 23, 2015. doi: 10.3390/ molecules 191118033 .

JOHNSON, C. et al. Xanthotoxin: A phytoalexin of Pastinaca sativa root. Phytochemistry, v.12,p.2961-2962, 1973. Available from: <https://www.researchgate.net/publication/256312937 Xanthotoxin_A_phytoalexin_of_Pastinaca_sativa_root $>$. Accessed: Jun. 23, 2015. doi: 10.1016/0031-9422(73)80515-1.

KEEN, N.T.; LITTLEFIELD, L.J. The possible association of phytoalexins with resistant gene expression in flax to Melamspora lini. Physiology Plant Pathology, v.14, p.275280, 1975. Available from: <http://www.sciencedirect.com/ science/article/pii/0048405979900481>. Accessed: Jun.23, 2015. doi:10.1016/0048-4059(79)90048-1.

KOGA, J. et al. Functional moiety for the antifungal activity of phytocassane E, a diterpenephytoalexin from rice. Phytochemistry, v.44, p.249-253, 1997. Available from: <http:// www.sciencedirect.com/science/article/pii/S0031942296005341>. Accessed: Jun. 14, 2015. doi: 10.1016/S0031-9422(96)00534-1.

KOGA, J. et al. Phytocassanes A, B, C and D, novel diterpenephytoalexins from rice, Oryza sativa L. Tetrahedron Letters, v.51, p.7907-7918, 1995. Available from: <http://www. sciencedirect.com/science/article/pii/0040402095004236>. Accessed: Jun. 14, 2015. doi:10.1016/0040-4020(95)00423-6.

KOKUBUN, T.; HARBORNE, J.B. Phytoalexin induction in the sapwood of plants of the Maloideae (Rosaceae): Biphenyls or dibenzofurans. Phytochemistry, v.40, p.1649-1654, 1995. Available from: <http:/www.sciencedirect.com/science/ article/pii/003194229500443B $>$. Accessed: Jun. 14, 2015. doi:10.1016/0031-9422(95)00443-B.

KODAMA, O. et al. Sakuretin, a flavanone phytoalexin from ultraviolet - irradiated rice leaves. Phytochemistry, v.31, n.11, p.3807-3809, 1992. Available from: <http://www.sciencedirect. com/science/article/pii/S0031942200975320>. Accessed. Jun.14, 2015. doi:10.1016/S0031-9422(00)97532-0.

LANGCAKE, P.; PRYCE, R.J. The production of resveratrol by Vitis vinifera and other members of the Vitaceae as a response to infection or injury. Physiology Plant Pathology, v.9, p.77-86, 1976. Available from: $\quad<$ https://www.researchgate.net/publication/222724546 Production_of_resveratrol_by_Vitis_vinifera_and_other_members of_Vitaceae_as_a_response_to_infection_or_injury $>$. Accessed: Jun. 14, 2015. doi: $10.1016 / \overline{0048}-4059(7 \overline{6}) 90077-1$.

LEE, C.W. et al. Momilactones A and B in rice straw harvested at different growth stages. Bioscience Biotechnology and Biochemisty, v.63, p.1318-1320, 1999. Available from: <http:// www.tandfonline.com/doi/abs/10.1271/bbb.63.1318>. Accessed: Ago. 23, 2015. doi: 10.1271/bbb.63.1318.

LI, Y. et al. Comparative proteomic analysis of methyl jasmonate induced defense responses in different rice cultivars. Journal of Proteomics, v.14, n9, p.1088-10101, 2014. Available from: $<$ http://www.ncbi.nlm.nih.gov/pubmed/24505015>. Accessed: Ago.23, 2015. doi: 10.1002/pmic.201300104.

LIN PARK, $\mathrm{H}$. et al. Transcriptomic analysis of UV-treated rice leaves reveals UV-induced phytoalexin biosynthetic pathways and their regulatory networks in rice. Phytochemistry, v.96, p.57-71, 2013. Available from: <http://www.ncbi.nlm.nih.gov/ pubmed/24035516>. Accessed: Ago. 23, 2015. doi: 10.1016/j. phytochem.2013.08.012.

MATEOS, R.G; LEAL, R.P. Fitoalexinas: mecanismo de defensa de las plantas. Review Chapingo Serie Cie, v.9, n.1, p.5-10, 2003. Available from: $<$ http://www.chapingo.mx/revistas/revistas/ articulos/doc/rchscfaIX383.pdf $>$. Accessed: Ago. 23, 2015. ISSN: 2007-3828.

MIKKELSEN, M.D. et al. Modulation oh CYP79 genes and glucosilate profiles in Arabidopsis by defense pathawys. Plant physiology, v.131, p.298-308, 2003. Available from: < http://www. ncbi.nlm.nih.gov/pmc/articles/PMC166809/>. Accessed: Ago.23, 2015. doi: 10.1104/pp.011015.

NUGROHO, L.H. et al. It is the accumulation of sesquiterpenephytoalexins induced in plants tobacco constitutively producing salicylic acid?. Plant science, v.162, n.6, p.989-993, 2002.Available from: <http://www.sciencedirect.com/science/ article/pii/S0168945202000493>. Accessed: Ago.22, 2015. doi:10.1016/S0168-9452(02)00049-3.

OKADA, A. et al. Elicitor induced activation of the methylerythritol phosphate pathway toward phytoalexins biosynthesis in rice. Plant Molecular Biology, v.65, p.177-187, 2007. Available from: $<$ http://www.ncbi.nlm.nih.gov/pubmed/17634747>. Accessed: Ago.22, 2015. doi: 10.1007/s11103-007-9207-2.

PEDRAS, M.S.C. et al. Phytoalexins from crucifers: Synthesis, biosynthesis and biotransformation. Phytochemistry, v.53, p.161-176, 2000. Available from: <http://www.sciencedirect. com/science/article/pii/S003194229900494X> Accessed: Ago.12, 2015. doi:10.1016/S0031-9422(99)00494-X.

PEDRAS, M.S.C. et al. Detection, characterization and identification of crucifer phytoalexins using high-performance liquid chromatography with diode array detection and electrospray ionization mass spectrometry. Journal of Chromatography A, v.1133, p.172-183, 2006. Available from: <http://www. sciencedirect.com/science/article/pii/S0021967306015366>. Accessed: Ago.12, 2015. doi: 10.1016/j.chroma.2006.08.015.

PIETERSE, C.M.J. et al. Rhizobacteria-mediated induce systemic resistance: triggering, signaling, and expression. European Journal of Plant Pathology, v.107, p.51-61, 2001. Available from: $<$ http://link.springer.com/article/10.1023/A:1008747926678>. Accessed: Ago.10, 2015. doi: 10.1023/A:1008747926678.

POLONI, A.; SCHIRAWSKI, J. Red card for pathogens: Phytoalexins in sorghum and maize. Molecules, v.19, p.91149133, 2014. Available from: <http://www.mdpi.com/14203049/19/7/9114>. Accessed: Ago.10, 2015. doi: 10.3390/ molecules 19079114

SÁNCHEZ-KEN, J.G. et al. Reinstatement and emendation of subfamily Micrairoideae (Poaceae). System Botany, v.32, p.71-80, 2007. Available from: <http://www.bioone.org/doi/pd f/10.1600/036364407780360102>. Accessed: Ago.10, 2015. doi: 10.1600/036364407780360102.

SHIMIZU, T. et al. Effects of a bile acid elicitor, acid cholic, on the biosynthesis of diterpenoid phytoa lexin in suspension cultured rice cells. Phytochemistry, v.69, n.4, p.973-981, 2008. Available from: $<$ http://www.sciencedirect.com/science/article/pii/ 
S0031942207006097>. Accessed: Ago.10, 2015. doi:10.1016/j. phytochem.2007.10.005.

SITTON, D.; WEST, C.A. CASBENE: an antifungal diterpene produced in cell-free extracts of Ricinus communis seedlings. Phytochemistry, v.14, p.1921-1925, 1975. Available from: <http:// www.sciencedirect.com/science/article/pii/0031942275830986>. Accessed: Ago.10, 2015. doi: 10.1016/0031-9422(75)83098-6.

SMITH, C.J. Accumulation of phytoalexins: defense mechanism and stimulus response system. New Phytologist, v.132, n.1, p.1-45, 1996. Available from: <http://onlinelibrary.wiley.com/ doi/10.1111/j.1469-8137.1996.tb04506.x/epdf>. Accessed: Ago.10, 2015. doi: 10.1111/j.1469-8137.1996.tb04506.x.

STOESSL, A. Phytoalexins - a biogenetic perspective. Journal of Phytopathology, v.99, n.3, p.251-272, 1980. Available from $<$ http://onlinelibrary.wiley.com/doi/10.1111/j.1439-0434.1980. tb03786.x/pdf>. Accessed: Ago. 10, 2015. doi: 10.1111/j.14390434.1980.tb03786.x.

SUNILKUMAR, G. Engineering cottonseed for use in human nutrition by tissue-specific reduction of toxic gossypol. In: Proceedings of the National Academy of Sciences, v.103, p.18054-18059, 2006. Available from: <http://www.pnas.org/ lens/pnas/103/48/18054>. Accessed: Ago. 12, 2015. doi: 10.1073/ pnas.0605389103.

TAKASUGI, M. et al. Structures of moracins E, F, G and H, new phytoalexins from diseased mulberry. Tetrahedron Letter, v.28, p.4675-4678, 1979. Available from: <http://www.sciencedirect. com/science/article/pii/S0040403901866806> . Accessed: Ago. 10, 2015. doi: 10.1016/S0040-4039(01)86680-6.

TOYOMASU, T. et al. Diterpene phytoalexins are biosynthesized in and exuded from the roots of rice seedlings. Bioscience biotechnology biochemistry, v.72, n.2, p.562-567, 2008. Available from: <http://www.tandfonline.com/doi/abs/10.1271/bbb.70677> . Accessed: Ago. 10, 2015. doi: 10.1271/bbb. 70677 .

URITANI, I. et al. Similar metabolic alterations induced in sweet potato by poisonous chemicals and by Ceratostomella fimbriata. Phytopathology, v.50, p.30-34, 1960. Available from: <http:// www.cabdirect.org/abstracts/19601101602.html? freeview $=$ true $>$. Accessed: Ago.10, 2015. ISSN 0031-949X.

VRANOVA E.C.D; GRUISSEM, W. Network analysis of the MVA and MEP pathways for isoprenoid synthesis. Review of Plant Biology, v.64, p.665-700, 2013. Available from: <http:// www.ncbi.nlm.nih.gov/pubmed/23451776>. Accessed: Ago.10, 2015. doi: 10.1146/annurev-arplant-050312-120116.

WARD, E.W.B. et al. Loroglossol: an orchid phytoalexin. Phytopathology, v.65, p.632-633, 1975. Available from: <https:// www.apsnet.org/publications/phytopathology/backissues/ Documents/1975Abstracts/Phyto65_632.htm>. Accessed: Ago.10, 2015. doi: 10.1094/Phyto-65-632.

WELKER, C.A.D.; LONGHI-WAGNER, H.M.L. A família Poaceae no Morro Santana, Rio Grande do Sul, Brasil. Revista Brasileira de Biociência. Porto Alegre, v.5, n.4, p.53-92, 2007. Available from: $<$ http://www.ufrgs.br/seerbio/ojs/index. php/rbb/article/viewFile/571/331>. Accessed: Ago.10, 2015. ISSN 1980-4849.

WHARTON, P.; NICHOLSON, R. Temporal synthesis and radiolabelling of the sorghum 3-deoxyanthocyanidin phytoalexins and the anthocyanin, cyanidin 3-dimalonyl glucoside. New Phytopatology, v. 145, p.457-469, 2000. Available from: <http:/ onlinelibrary.wiley.com/doi/10.1046/j.1469-8137.2000.00600.x/ full>. Accessed: Jul. 12, 2015. doi: 10.1046/j.14698137.2000.00600.x

WILDERMAN, P.R. et al. Identification of syn-pimara-7,15diene synthase reveals functional clustering of terpene synthases involved in rice phytoalexin/allele chemical biosynthesis. Plant Physiology, v.135, p.2098-2105, 2004. Available from: <http:// www.ncbi.nlm.nih.gov/pmc/articles/PMC520781/>. Accessed: Ago. 10,2015. doi: 10.1104/pp.104.045971.

ZHANG, J.; ZHOU, J.M. Plant immunity triggered by microbial molecular signatures. Molecular Plants, v.3, n5, p.783-793, 2010. Available from: <http://www.sciencedirect.com/science/ article/pii/S1674205214605323>. Accessed: Ago.10, 2015. doi: $10.1093 / \mathrm{mp} / \mathrm{ssq} 035$.

ZHANG, Y. et al. The genetic and molecular basis of plant resistance to pathogens. Journal of Genetics and Genomics, v.40, n.1, p.23-35, 2013. Available from: <http://www.ncbi nlm.nih.gov/pubmed/23357342>. Accessed: Jun. 10, 2015. doi: 10.1016/j.jgg.2012.11.003.

ZHANG, H. et al. Arabidopsis AtERF15 positively regulates immunity against Pseudomonas syringae pv. tomato DC3000 and Botrytis cinerea. Frontiers in Plant Science, v.6, p.686699, 2015. Available from: <http://www.ncbi.nlm.nih.gov/ pubmed/26388886>. Accessed: Ago. 15, 2015. doi: 10.3389/ fpls.2015.00686. 


\section{ERRATUM}

Artigo "An approach on phytoalexins: function, characterization and biosynthesis in plants of the family Poaceae" publicado no fascículo v46n7 de julho da Ciência Rural páginas 1206-1216, onde se lia:

"Key words: metabolites, protection of plants, signage, Oryza sativa."

leia-se:

"Key words: metabolites, protection of plants, signaling, Oryza sativa."

onde se lia:

"300 types have been characterized amongst different classes"

leia-se:

"300 types have been characterized among different classes"

onde se lia:

"influence of various factors as temperature"

leia-se:

"influence of various factors such as temperature"

onde se lia:

"explore the phytoalexins produced in various parts of plants"

leia-se:

"explore the produced phytoalexins in various parts of plants"

onde se lia:

"This can be explained by the absence of the specific elicitor phytoalexin for the gene expression of these plants, since it is of secondary metabolism products that is required phenotypic changes elicited by the action of biotic or abiotic agents."

leia-se:

"This gap can be explained by the lack either elicitors, biotic or abiotic, as specific genes that regulates the expression/activation of components of the metabolic pathways necessary for obtaining the phytoalexin molecule."

onde se lia:

"(GRAYER \& KOKUBUN, 2001). Thus, studies have been carried out to develop more resistant cultivars."

leia-se:

"(GRAYER \& KOKUBUN, 2001), despite the efforts what has been done by plant pathologists and breeders to develop resistant cultivars." 
onde se lia:

"MeOH and chloroform and liquid nitrogen"

leia-se:

"MeOH, chloroform and liquid nitrogen"

onde se lia:

"These two types of defense are considered as constituting"

leia-se:

"These two types of defense are considered as constitutive"

onde se lia:

"Once they are no pathogenic organisms, their mechanism of action is the induced systemic resistance, not causing symptoms such as necrosis and activating the defense response of plants such as the production of PRPs and phytoalexins."

leia-se:

"Once they are no pathogenic organisms, their mechanism of action to induces systemic resistance, by activating the defense response of plants such as the production of PRPs and phytoalexins."

onde se lia:

"Because these are compounds that are extracted from plants, they can present phytoalexins, which contribute to an increased expression of these compounds in plants used in the study."

leia-se:

"Once these are compounds that are extracted from plants, they can present phytoalexins, which contribute to increases expression of these compounds in plants used in the study."

onde se lia:

"execution of the insolation process makes"

leia-se:

"execution of the isolation process makes"

onde se lia:

"elicitors for each species studied becomes necessary, because once it comes secondary metabolism products; factors are needed for this induction."

leia-se:

"elicitors for each species needs also more studies to clarify what is the secondary metabolism product and metabolism elicitors."

onde se lia:

"metabolites produced or modified by a body, are tools available that can serve as a more complete process of analysis of phytoalexins. The molecular biology study became a strategy that has been extensively analyzed because knowledge"

leia-se:

"metabolites produced or modified by a organism, are tools available that can serve as a more complete process of analysis of phytoalexins. The molecular biology studies became a strategy that has been extensively analyzed because the knowledge"

Ciência Rural, v.46, n.8, ago, 2016. 
onde se lia:

"evaluate the discovery of new phytoalexins identification"

leia-se:

"evaluate the discovery of new phytoalexins and identification"

Para a versão correta, acesse:

http://www.scielo.br/pdf/cr/v46n7/1678-4596-cr-46-07-001206.pdf 